\title{
PHASE CHANGES ON 4H AND 6H SIC AT HIGH TEMPERATURE OXIDATION
}

\author{
Jan Setiawan, Ganisa K Suryaman, Masrukan K \\ Pusat Teknologi Bahan Bakar Nuklir-BATAN \\ Kawasan Puspiptek, Serpong, Tangerang Selatan, 15314 \\ e-mail: jansetiawan@batan.go.id
}

(Naskah diterima : 25-04-2016, Naskah direvisi: 17-05-2016, Naskah disetujui: 23-05-2016)

\begin{abstract}
PHASE CHANGES ON 4H AND 6H SIC AT HIGH TEMPERATURE OXIDATION. The oxidation on two silicon carbide contain $6 \mathrm{H}$ phase and contains $6 \mathrm{H}$ and $4 \mathrm{H}$ phases has been done. Silicon carbide is ceramic non-oxide with excellent properties that potentially used in industry. Silicon carbide is used in nuclear industry as structure material that developed as light water reactor (LWR) fuel cladding and as a coating layer in the high temperature gas-cooled reactor (HTGR) fuel. In this study silicon carbide oxidation simulation take place in case the accident in primary cooling pipe is ruptured. Sample silicon carbide made of powder that pressed into pellet with diameter $12.7 \mathrm{~mm}$ and thickness $1.0 \mathrm{~mm}$, then oxidized at temperature $1000{ }^{\circ} \mathrm{C}, 1200{ }^{\circ} \mathrm{C}$ dan $1400{ }^{\circ} \mathrm{C}$ for 1 hour. The samples were weighted before and after oxidized. X-ray diffraction conducted to the samples using Panalytical Empyrean diffractometer with $\mathrm{Cu}$ as $\mathrm{X}$-ray source. Diffraction pattern analysis has been done using General Structure Analysis System (GSAS) software. This software was resulting the lattice parameter changes and content of SiC phases. The result showed all of the oxidation samples undergoes weight gain. The $6 \mathrm{~S}$ samples showed the highest weight change at oxidation temperature $1200{ }^{\circ} \mathrm{C}$, for the $46 \mathrm{~S}$ samples showed increasing tendency with the oxidation temperature. X-ray diffraction pattern analysis showed the $6 \mathrm{~S}$ samples contain dominan phase $6 \mathrm{H}-\mathrm{SiC}$ that matched to ICSD 98-001-5325 card. Diffraction pattern on $6 S$ showed lattice parameter, composition and crystallite size changes. Lattice parameters changes had smaller tendency from the model and before oxidation. However, the lowest silicon carbide composition or the highest converted into other phases up to $66.85 \%$, occurred at oxidation temperature $1200^{\circ} \mathrm{C}$. The $46 \mathrm{~S}$ samples contains two polytypes silicon carbide. The $6 \mathrm{H}-\mathrm{SiC}$ phases matched by ICSD $98-016-4972$ card and $4 \mathrm{H}-\mathrm{SiC}$ phase matched by ICSD 98-016-4971 card. Diffraction pattern on 46S also showed lattice parameter, composition and crystallite size changes. The lattice parameter changes not significant. For $6 \mathrm{~S}$ and $46 \mathrm{~S}$ samples at $1400{ }^{\circ} \mathrm{C}$, the $6 \mathrm{H}-\mathrm{SiC}$ phase changes into other phases more than $50 \%$ from its original weight percentage.
\end{abstract}

Keywords: silicon carbide, $4 \mathrm{H}-\mathrm{SiC}, 6 \mathrm{H}-\mathrm{SiC}$, oxidation, high temperature. 


\section{ABSTRAK}

\section{PERUBAHAN FASA 4H DAN 6H SIC YANG TEROKSIDASI PADA TEMPERATUR TINGGI.}

Telah dilakukan proses oksidasi pada silikon karbida yang mengadung fasa $6 \mathrm{H}$ dan silikon karbida yang mengandung fasa $4 \mathrm{H}$ dan $6 \mathrm{H}$. Silikon karbida merupakan keramik non oksida dengan sifat-sifat unggulnya yang sangat potensial digunakan dalam dunia industri. Dalam industri nuklir silikon karbida digunakan sebagai bahan struktur kelongsong pada bahan bakar reaktor air ringan light water reactor (LWR) dan sebagai pelapis pada kernel bahan bakar reaktor gas temperatur tinggi (RGTT). Pada studi ini dilakukan simulasi oksidasi silikon karbida pada kernel apabila terjadi kegagalan pada pipa pendingin utamanya. Sampel dibentuk dari serbuk silikon karbida yang di pres hingga berbentuk pelet dengan diameter 12,7 mm dan ketebalan 1.0 $\mathrm{mm}$ kemudian dioksidasi pada temperatur $1000^{\circ} \mathrm{C}, 1200^{\circ} \mathrm{C}$ dan $1400^{\circ} \mathrm{C}$ selama 1 jam. Sampel sebelum dan setelah dioksidasi dilakukan penimbangan dan pengujian difraksi sinar- $X$ menggunakan Difraktometer Panalytical Empyrean dengan Cu sebagai sumber sinar- $X$. Analisis pola difraksi dilakukan menggunakan aplikasi General Structure Analysis System (GSAS), dengan hasil yang diperoleh adalah perubahan parameter kisi dan kandungan fasa SiC-nya. Hasil percobaan menunjukkan bahwa semua sampel yang teroksidasi mengalami peningkatan berat. Oksidasi sampel $6 S$ menyebabkan kenaikan berat tertinggi pada temperatur $1200{ }^{\circ} \mathrm{C}$, sedangkan sampel $46 S$ memiliki berat dengan kecenderungan meningkat seiring dengan meningkatnya temperatur oksidasi. Analisis pola difraksi sinar- $X$ menunjukkan bahwa fasa dominan yang terbentuk pada sampel $6 \mathrm{~S}$ adalah fasa $6 \mathrm{H}$-SiC yang didekati dengan model dari kartu ICSD 98-001-5325. Pola difraksi sampel 6S menunjukkan adanya perubahan parameter kisi, perubahan komposisi dan perubahan ukuran kristalitnya. Perubahan panjang kisi memiliki kencenderungan berkurang dari nilai model dan sebelum dioksidasi, sedangkan komposisi silikon karbida paling rendah atau yang paling banyak terkonversi menjadi fasa lain mencapai $66.85 \%$, yang terjadi pada temperatur oksidasi $1200^{\circ} \mathrm{C}$. Sampel $46 \mathrm{~S}$ mengandung fasa $4 \mathrm{H}-\mathrm{SiC}$ dan $6 \mathrm{H}$ SiC. Fasa 6H-SiC didekati dengan model dari kartu ICSD 98-016-4972 dan fasa 4H-SiC didekati dengan model dari kartu ICSD 98-016-4971. Pola difraksi sampel 46S menunjukkan adanya perubahan parameter kisi, perubahan komposisi dan perubahan ukuran kristalitnya. Perubahan panjang kisi pada sampel $46 \mathrm{~S}$ tidak terlalu signifikan. Fasa $6 \mathrm{H}$-SiC pada sampel $6 \mathrm{~S}$ dan $46 \mathrm{~S}$ dengan temperatur oksidasi $1400{ }^{\circ} \mathrm{C}$ mengalami perubahan menjadi fasa oksida dan lainnya sebesar lebih dari $50 \%$ persen berat awalnya.

Kata kunci: silikon karbida, 4H-SiC, 6H-SiC, oksidasi, temperatur tinggi. 


\section{INTRODUCTION}

Silicon carbide (SiC) is ceramic material with properties high hardness, low bulk density and high oxidation resistance which make SiC suitable for a wide range of industrial applications ${ }^{[1]}$. SiC widely used as refractory material ${ }^{[2]}$ that also interest in using as the nuclear fuel cladding material in light water reactor (LWR) ${ }^{[3,4]}$ and as coating layer in high temperature gas cooled reactor (HTGR) fuel ${ }^{[5]}$. Sintering of silicon carbide was first performed by Prochazka by using boron and carbon through a solid state mechanism that performed at $2150-2200^{\circ} \mathrm{C}{ }^{[1]}$. Silicon carbide in nature can be found as extremely rare mineral called moissanite [2]. It was first discovered by $\mathrm{H}$. Moissan on meteorite located in the Diablo Canyon of Arizona in 1893. In 1891, E. G. Acheson synthesized silicon carbide in the laboratory and named as 'Carborundum' [2]. SiC has two major polytypes, which are alpha SiC ( $\alpha$ $\mathrm{SiC}$ ) having hexagonal crystal structure (similar to Wurtzite) and the beta modification ( $\beta-\mathrm{SiC})$, with a zinc blende crystal structure (similar to diamond) [2]. SiC exits in various crystallographic phases with more than 170 polytypes. Despite lower carrier mobilities compared to $\beta-\mathrm{SiC}$, hexagonal $4 \mathrm{H}$ and $6 \mathrm{H} \mathrm{SiC}$ polytypes are the most commonly used for devices because of good quality crystal wafer availability and larger bandgap.

$\mathrm{SiC}$ is a non-oxide and it has the tendency to get oxidized in presence of oxygen or oxidizing agents ${ }^{[2]}$. Oxidation of $\mathrm{SiC}$ based materials is also an important issue. The oxidation of $\mathrm{SiC}$-based material generally can be different into two oxidation regimes: active and passive oxidation [2,4]. The oxidation behavior depends on the oxidizing conditions such as the oxidizing species, temperature, total pressure, and partial pressure of the oxidant ${ }^{[2,4,6]}$. The particle size also strongly influences the kinetics oxidation, where the weight gain and rate constant increasing with decreasing the
SiC particle size ${ }^{[7]}$. In active oxidation, at low oxygen partial pressures and high temperatures, non-protective oxide film formation is expected as a result of significant $\mathrm{SiO}$ vapor formation:

$\mathrm{SiC}(\mathrm{s})+\mathrm{O}_{2}(\mathrm{~g}) \rightarrow \mathrm{SiO}(\mathrm{g})+\mathrm{CO}(\mathrm{g})$

$\mathrm{SiO}_{2}$ formed gets vaporized after its formation leading to loss of mass. In contrast, passive oxidation occurs at high oxygen partial pressures and very high temperatures. In passive oxidation, a protective $\mathrm{SiO}_{2}$ layers forms according to:

$\mathrm{SiC}(\mathrm{s})+3 / 2 \mathrm{O}_{2}(\mathrm{~g}) \rightarrow \mathrm{SiO}_{2}(\mathrm{~s})+\mathrm{CO}(\mathrm{g})$

$\mathrm{SiO}_{2}$ forms during passive oxidation get deposited over the surface of SiC leading to net increase in the mass. It was observed that $\mathrm{SiO}_{2}$ formed at lower temperature develops layer over the surface of SiC and protects it from further oxidation to $\mathrm{SiO}$ occurred at higher temperatures. These protective action continues up to the melting point of $\mathrm{SiO}_{2}$ at $1996 \mathrm{~K}$ [2]. Hijikata ${ }^{[8]}$ proposed $\mathrm{Si}$ and $\mathrm{C}$ emission model for mechanism $\mathrm{SiC}$ oxidation. Figure 1, illustrated the $\mathrm{Si}$ and $\mathrm{C}$ emission model for $\mathrm{SiC}$ oxidation. Considering $\mathrm{Si}$ and $\mathrm{C}$ atoms emitted from the interface during the oxidation as well as the oxidation process of $\mathrm{C} . \mathrm{X}$ is denote as the oxide thickness. In this model the oxide growth rate well reproduces over the entire thickness range for both the $\mathrm{C}$ and $\mathrm{Si}$ faces. Describing the oxide growth process in $\mathrm{SiC}$ needed the oxidation and emission of $\mathrm{C}$ and the emission Si take into account. In case the absence of interstitial accumulation and $\mathrm{Si}$ emission rate might be contributing to the large difference in oxide growth rate between the polar faces ${ }^{[9]}$. A face terminated oxidation behavior on $4 \mathrm{H}-\mathrm{SiC}$ has been observed which indicates that the oxidation growth rate on $\mathrm{C}$-face is faster than on $\mathrm{Si}$ face ${ }^{[10]}$. The oxide layer thickness increased slowly below $1200{ }^{\circ} \mathrm{C}$ and rapidly when the temperatures are higher than $1500{ }^{\circ} \mathrm{C}^{[11]}$. This term oxidation process can use as film growth on SiC surface that applicable in electronic devices ${ }^{[12]}$. 
$\mathrm{SiC}$ in kernel nuclear fuel is provide a crucial safety in this nuclear system. SiC layer is considered the most importance since not only provides the TRISO particle with structural integrity but also it is the primary layer for containing radioactive fission products at elevated temperatures. Test on safety have been carried out to study the performance of this SiC coating layer. Result revealed several potential failure mechanisms of the SiC layer, which included pressure vessel failure caused by internal gas pressure and irradiation stress, chemical corrosion and thermal decomposition at very high temperatures. Many postulated accidents must also be taken into account in evaluating the reliability of the SiC layer. Air ingress is among the postulated accidents in HTGR. Under normal operation conditions of an HTGR reactor, the fuels work in helium loops and are isolated from air by several protective barriers. However postulated accidents in which a primary coolant pipe is ruptured, air invades the reactor core. The fuel sphere might be exposed to air [11]. Furthermore, the oxidation results obtained can also provide information of $\mathrm{SiC}$ phase changes during oxidation.

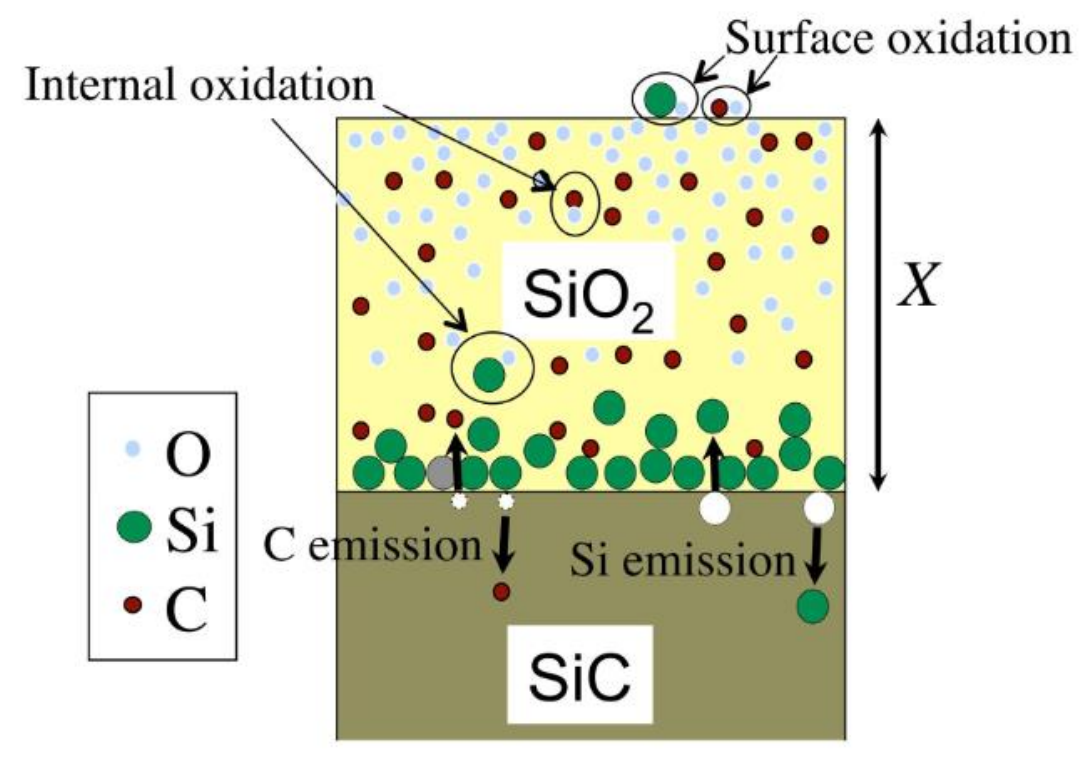

Figure 1. Schematic mechanism SiC oxidation ${ }^{[8]}$

$\mathrm{SiC}$ in kernel nuclear fuel is provide a crucial safety in this nuclear system. SiC layer is considered the most importance since not only provides the TRISO particle with structural integrity but also it is the primary layer for containing radioactive fission products at elevated temperatures. Test on safety have been carried out to study the performance of this SiC coating layer. Result revealed several potential failure mechanisms of the SiC layer, which included pressure vessel failure caused by internal gas pressure and irradiation stress, chemical corrosion and thermal decompo- sition at very high temperatures. Many postulated accidents must also be taken into account in evaluating the reliability of the $\mathrm{SiC}$ layer. Air ingress is among the postulated accidents in HTGR. Under normal operation conditions of an HTGR reactor, the fuels work in helium loops and are isolated from air by several protective barriers. However postulated accidents in which a primary coolant pipe is ruptured, air invades the reactor core. The fuel sphere might be exposed to air [11]. Furthermore, the oxidation results obtained can also 
provide information of $\mathrm{SiC}$ phase changes during oxidation.

In this study, investigation and comparison of the phase changes on the $\mathrm{SiC}$ in which containing only the $6 \mathrm{H}$ polytype with combining polytype silicon carbide the $4 \mathrm{H}$ and $6 \mathrm{H}$ - polytypes relating to the high temperature oxidation has been carried out. The samples were oxidized at temperature $1000{ }^{\circ} \mathrm{C}, 1200{ }^{\circ} \mathrm{C}$, and $1400{ }^{\circ} \mathrm{C}$ for 1 hour and the tests were conducted in air atmosphere. The weight changes on samples were analyzed by analytical balance. As a passive oxidation occur in this experiment, the sample showed weight gain after oxidation ${ }^{[2,4]}$. The phase changes of the SiC samples were observed by the X-ray diffractometer (XRD). The relationship between the lattice parameter of SiC phase and weight changes was discussed.

\section{EXPERIMENTAL PROCEDURE}

The material used in this study were polycrystalline SiC. The samples were prepared in pellet form, with dimensions of approximately diameter $12.7 \mathrm{~mm}$ and thickness $1.0 \mathrm{~mm}$. Sample with phase only $6 \mathrm{H}-\mathrm{SiC}$ coded by $6 \mathrm{~S}$ and sample containing $4 \mathrm{H}-\mathrm{SiC}$ and $6 \mathrm{H}-\mathrm{SiC}$ coded by $46 \mathrm{~S}$. A heating furnace of thermolyne was used to oxidation the samples. All of tests were conducted with heating rate at $10{ }^{\circ} \mathrm{C} / \mathrm{min}$ to the desired temperature achieved. The samples were oxi-dized for 1 hour in the air atmosphere and the cooling rate at $5{ }^{\circ} \mathrm{C} / \mathrm{min}$ until reached the room temperature while the samples still inside the furnace chamber. The oxidation temperatures were conducted at $1000{ }^{\circ} \mathrm{C}, 1200{ }^{\circ} \mathrm{C}$ and $1400{ }^{\circ} \mathrm{C}$ in air atmosphere. Analytical balance was used to weighted the samples before and after the oxidation. In order to observe the structural change on the samples by X-ray diffraction, the Panalytical Empyrean diffractometer with The Cu X-ray source was used. During the $\mathrm{X}$-ray Diffraction process the $\mathrm{X}$-ray source tension parameter was set at $40 \mathrm{kV}$ and current parameter was set at $30 \mathrm{~mA}$ with time per step at $1 \mathrm{~s}$. The analysis of the diffraction pattern was performed by the General Structure Analysis System (GSAS) software.

\section{RESULT AND DISCUSSION}

Results from the analytical balance of the samples weight changes represented at Figure 2. The sample showed weight gain after oxidation as reported by $[2,4]$. These weight values were combination of the SiC phase(s) and the other phases that formed during oxidation. The $6 \mathrm{~S}$ oxidation weight changes percentage at $1000{ }^{\circ} \mathrm{C}$ was $4.55 \%$, and the change continues increased. The higher percentage was the oxidation at $1200{ }^{\circ} \mathrm{C}$, where the changes reached $24.44 \%$. The samples oxidation for $46 \mathrm{~S}$, showed lower oxidation weight changes percentage. The higher percentage was occurred at $1400{ }^{\circ} \mathrm{C}$, with percentage reached $5.30 \%$. The next section will show the phase that affected the weight changes.

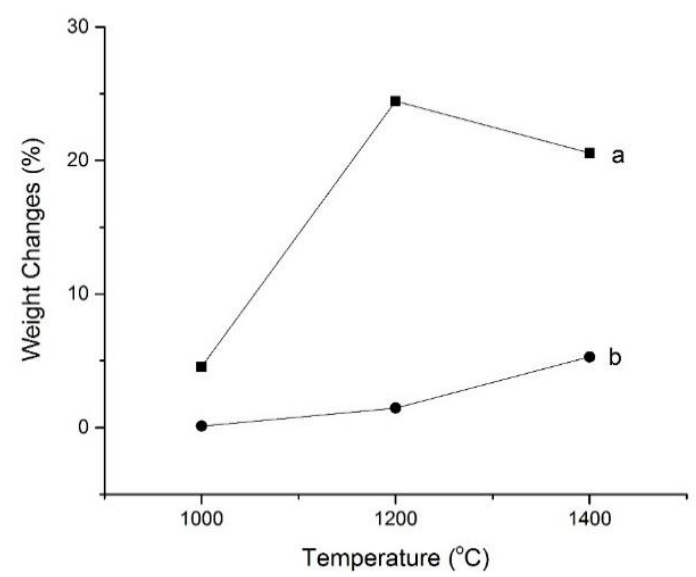

Figure 2. Weight changes of (a) $6 \mathrm{~S}$ and (b) 46S during oxidation under air atmosphere

\section{a. Silicon carbide containing $6 \mathrm{H}$ polytype (6H-SiC or $6 \mathrm{~S}$ )}

The diffraction pattern in Figure 3 showed for samples $6 S$ and the oxidation samples. The oxidation diffraction patterns showed another phases formed beside the $6 \mathrm{H}-\mathrm{SiC}$ phase. During the oxidation, there 
were interaction induced by heat between oxygen with silicon carbide while temperature increase. The diffraction pattern showed peak shifted and there some broadening peaks. Shifted peaks indicating there were lattice parameter changes and the broadening peaks there were changes in crystallite size. The original lattice parameters and the changes for $6 \mathrm{H}-\mathrm{SiC}$ phases were tabulated in Table 1. Some peaks broadening tabulated in Table 2 .

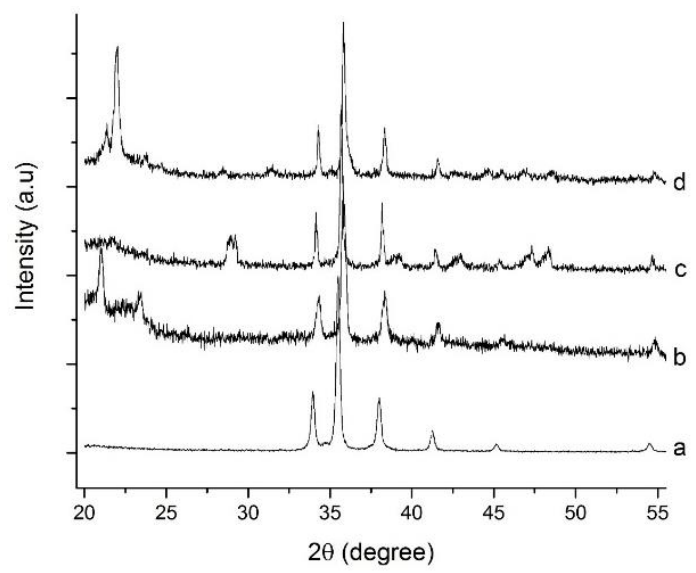

Figure 3. Diffraction patterns of $\mathrm{SiC} 6 \mathrm{H}$ polytype, (a) without oxidation (as received) and oxidation at (b) 1000 ${ }^{\circ} \mathrm{C}$, (c) $1200^{\circ} \mathrm{C}$, and (d) $1400{ }^{\circ} \mathrm{C}$ under air atmosphere.

The original phases in the $6 \mathrm{~S}$ was mossainate $6 \mathrm{H}$ that matched to the card 98001-5325 from ICSD data base. These refined parameters were analyzed by GSAS software using the Rietveld method [13-14]. The original model for analyzed all the samples for 65 was based on the ICSD card 98-001-5325 [15]. The matched phases on the oxidation samples not only $6 \mathrm{H}-\mathrm{SiC}$ appear, there were other several crystalline phases form the oxygen-silicon carbide interaction such as silicon dioxide. The other phases not for our concerns now.

The Rietveld method results for 65 showed changes in a-axis and c-axis values. The as received $\mathrm{SiC}$ had higher a-axis and c-axis values compared to the model. The lattice parameters all of oxidation samples changes compared the as received SiC. The lattice parameters values showed decreasing at $1000^{\circ} \mathrm{C}$, and then increasing again for $1200{ }^{\circ} \mathrm{C}$ and $1400{ }^{\circ} \mathrm{C}$, but the values still lower than the as received SiC. The lower lattice parameters values for $6 \mathrm{~S}$ indicating had smaller volume and possibility had higher density. The $6 \mathrm{H}-\mathrm{SiC}$ phase weight changes in the oxidation samples was higher at the oxidation temperature $1200{ }^{\circ} \mathrm{C}$. In Figure 2, the weight changes percentage for $6 \mathrm{~S}$ showed higher changes at $1200{ }^{\circ} \mathrm{C}$ in this case correlate to the weight percentage for other phases, which is the higher weight percentage value about $66.85 \%$. The $6 \mathrm{~S}$ than contain only $6 \mathrm{H}-\mathrm{SiC}$ indi-cate the oxidation at high temperature its weight changes were significantly influenced by other phases that formed during oxidation. The oxide phases were formed slowly below $1200{ }^{\circ} \mathrm{C}$ [11]. At $1400^{\circ} \mathrm{C}$ the oxide layer in the surface of $\mathrm{SiC}$ already reached saturation where there no more emission of $\mathrm{Si}$ and $\mathrm{C}$ atoms from the surface of $\mathrm{SiC}$ or internal of oxide layer. Peaks detection in as received $\mathrm{SiC}$ for the three peaks with higher intensities were tabulated in Table 2.

Table 1. Phase contents in the $6 \mathrm{~S}$

\begin{tabular}{|c|c|c|c|c|c|}
\hline Parameter & Model & w/o oxidation & $1000^{\circ} \mathrm{C}$ & $1200^{\circ} \mathrm{C}$ & $1400^{\circ} \mathrm{C}$ \\
\hline \multicolumn{6}{|l|}{$\begin{array}{l}\text { Moissanite } 6 \mathrm{H} \\
98-001-5325^{[15]}\end{array}$} \\
\hline \multirow{6}{*}{$\begin{array}{l}\text { Crystal system: } \\
\text { Space group: } \\
a=b=(\AA): \\
c=(\AA): \\
\text { Alpha=Beta }\left(^{\circ}\right): \\
\text { Gamma }\left(^{\circ}\right):\end{array}$} & Hexagonal & Hexagonal & Hexagonal & Hexagonal & Hexagonal \\
\hline & P 63 m c & P 63 m c & P 63 m c & P 63 m c & P63 m c \\
\hline & 3.0810 & $3.08360(3)$ & $3.072658(5)$ & $3.07982(6)$ & $3.08073(8)$ \\
\hline & 15.1170 & $15.13064(5)$ & $15.08227(7)$ & 15.11628(2) & $15.11531(1)$ \\
\hline & 90 & 90 & 90 & 90 & 90 \\
\hline & 120 & 120 & 120 & 120 & 120 \\
\hline
\end{tabular}




\begin{tabular}{|l|l|l|l|l|}
\hline Wt\%: & 100.000 & 74.266 & 33.152 & 47.548 \\
\hline Other phases: & & 25.743 & 66.848 & 52.452 \\
\hline Wt\%: &
\end{tabular}

Table 2. Peaks of $\mathrm{SiC} 6 \mathrm{H}$ polytype.

\begin{tabular}{|c|c|c|c|c|c|}
\hline $2 \theta$ (degree) & SiC Polytype & \multicolumn{4}{|c|}{ FWHM } \\
\cline { 3 - 6 } (w/o oxidation) & & w/o oxidation & $1000{ }^{\circ} \mathrm{C}$ & $1200{ }^{\circ} \mathrm{C}$ & $1400{ }^{\circ} \mathrm{C}$ \\
\hline 34.107 & $6 \mathrm{H}$ & 0.160 & 0.240 & 0.080 & 0.120 \\
\hline 35.574 & $6 \mathrm{H}$ & 0.260 & 0.080 & 0.140 & 0.140 \\
\hline 59.860 & $6 \mathrm{H}$ & 0.200 & 0.080 & 0.100 & 0.100 \\
\hline
\end{tabular}

According to the without oxidation sample the broadening peaks analyzed through the Full Width at Half Maximum (FWHM) value. In the peak at 35.574 degree and 59.860 degree there were decreasing FWHM value in the oxidation at $1000^{\circ} \mathrm{C}$ and had similar FWHM value in the oxidation at $1200^{\circ} \mathrm{C}$ and $1400^{\circ} \mathrm{C}$. Different to the peak at 34.107 degree that changes to oxidation temperature. This FWHM value changes phenomena occurs for each peaks. These meant the crystallite size changes with the temperature oxidation. At $1000^{\circ} \mathrm{C}$ the crystallite size was decreasing compare to the original crystallite size. At $1200^{\circ} \mathrm{C}$ the crystallite size was increasing compared at $1000{ }^{\circ} \mathrm{C}$, and at $1400{ }^{\circ} \mathrm{C}$ was decreasing but still bigger compared the original crystallite size.

\section{b. Silicon carbide containing $4 \mathrm{H}$ and $6 \mathrm{H}$ polytype (4H-SiC and $6 \mathrm{H}-\mathrm{SiC}$ or $46 \mathrm{~S}$ )}

The diffraction pattern changes during oxidation process for $46 \mathrm{~S}$ showed in Figure 4. The phases changes can be observed by several peaks from $\mathrm{SiC} 4 \mathrm{H}$ polytype and $\mathrm{SiC} 6 \mathrm{H}$ polytype. The diffraction pattern also showed peak shifted as the $6 \mathrm{H}-\mathrm{SiC}$ and there also some broadening peaks. The original lattice parameters and the changes for $4 \mathrm{H}-\mathrm{SiC}$ and $6 \mathrm{H}-\mathrm{SiC}$ phases were tabulated in Table 3. Table 4 showed the corresponding peaks to each of SiC polytype.

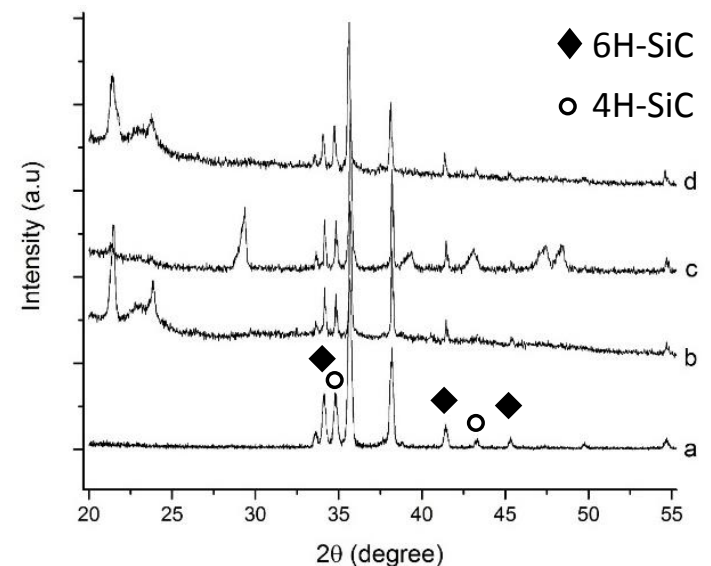

Figure.4..Diffraction patterns of $\mathrm{SiC}$ containing $4 \mathrm{H}$ and $6 \mathrm{H}$ polytype, (a) without oxidation (as received) and oxidation at (b) $1000^{\circ} \mathrm{C}$, (c) 1200 ${ }^{\circ} \mathrm{C}$, and (d) $1400{ }^{\circ} \mathrm{C}$ under air atmosphere. Tick marks indicate non overlapping peak between $4 \mathrm{H}$ and $6 \mathrm{H}$.

The original phase of the $4 \mathrm{H}$-silicon carbide was matched to the card 98-016$4971{ }^{[15]}$ and the $6 \mathrm{H}$-silicon carbide was matched to the card 98-016-4972 [15], the both cards were taken from ICSD data base. These refined parameters were analyzed by GSAS software using the Rietveld method. The original model for analyzed all the samples were based on the ICSD card 98016-4972 and 98-016-4971. The matched phases on the oxidation samples not only $4 \mathrm{H}-\mathrm{SiC}$ and $6 \mathrm{H}-\mathrm{SiC}$ phases, there were several phases form the oxygen-silicon carbide interaction such as silicon dioxide. These other phases not for our concerns now.

The Rietveld method for these samples also showed changes in a-axis and $\mathrm{c}$-axis value. The as received $\mathrm{SiC}$ had lower 
a-axis value but higher for c-axis value compared to the model. The lattice parameters values for $4 \mathrm{H}-\mathrm{SiC}$ and $6 \mathrm{H}-\mathrm{SiC}$ changes during the oxidation. For $6 \mathrm{H}-\mathrm{SiC}$, only at $1400{ }^{\circ} \mathrm{C}$ had a-axis and $\mathrm{C}$-axis values higher than as received $\mathrm{SiC}$. This indicate the $6 \mathrm{H}-\mathrm{SiC}$ that oxidated at $1400{ }^{\circ} \mathrm{C}$ had highest volume unit cell that affected to the density value become smaller compare to the as received $\mathrm{SiC}$. For $4 \mathrm{H}-\mathrm{SiC}$ during oxidation increasing occurred in lattice parameter. This indicate the samples had higher volume that possibility had smaller density compared to the as received SiC. The analysis result for the as received $\mathrm{SiC}$ content for $6 \mathrm{H}-\mathrm{SiC}$ were $62.717 \%$ and $37.283 \%$ for $4 \mathrm{H}-\mathrm{SiC}$. The content of each $\mathrm{SiC}$ polytype at $1000^{\circ} \mathrm{C}$ was lower compared to the as received SiC. At this temperature, more than $60 \%$ for each polytype $\mathrm{SiC}$ converted into other phases. At 1200 ${ }^{\circ} \mathrm{C}$, the percentage converted SiC decreasing down to around $37 \%$ for each polytypes of SiC. At the oxidation temperature $1400{ }^{\circ} \mathrm{C}$, the $6 \mathrm{H}-\mathrm{SiC}$ in the sample $46 \mathrm{~S}$ had more the oxygen uptake compared to the $4 \mathrm{H}-\mathrm{SiC}$. These state same as the $6 \mathrm{H}-\mathrm{SiC}$ at the samples $6 \mathrm{~S}$, where the converted $\mathrm{SiC}$ into other phase were more than $50 \%$ from it's original weight percentage. In Figure 2, the weight changes percentage for $46 \mathrm{~S}$ showed increasing changes that correlated to the weight percentage for $4 \mathrm{H}-\mathrm{SiC}$ phase. In the combination of $4 \mathrm{H}-$ and $6 \mathrm{H}-\mathrm{SiC}$ polytype, the $4 \mathrm{H}$ phase existence in the samples had the higher contribution into the $\mathrm{SiC}$ weight compared to the $6 \mathrm{~S}$ sample that other phases that containing the role majoring by oxide phase.

Same as to the $6 \mathrm{H}$-SiC samples these $46 \mathrm{~S}$ samples the broadening peaks analyzed through the Full Width at Half Maximum (FWHM) value. The $6 \mathrm{H}-\mathrm{SiC}$ and $4 \mathrm{H}$-SiC phase had bigger crystallite size tendency along with increasing the temperature. Crystallite size of $6 \mathrm{H}-\mathrm{SiC}$ decreasing for peak at 45.330 degree at temperature $1000{ }^{\circ} \mathrm{C}$ and $1400{ }^{\circ} \mathrm{C}$. While, the $4 \mathrm{H}-\mathrm{SiC}$ phase happened for peak at 43.289 degree at all oxidation temperature.

Corresponding to the $\mathrm{SiC}$ oxidation, the mechanism in passive oxidation was formed a protective layer to inhibit further $\mathrm{SiC}$ oxidation. In our finding, at high temperature the $6 \mathrm{H}-\mathrm{SiC}$ more reactive to the air compared the $4 \mathrm{H}-\mathrm{SiC}$. This was showed by the weight percentage of $4 \mathrm{H}-\mathrm{SiC}$ in $46 \mathrm{~S}$ samples that relativly low converted into other phases during oxidation compared to the $6 \mathrm{H}$-SiC. 
Table 3. Phase contents in the 46S.

\begin{tabular}{|c|c|c|c|c|c|}
\hline Parameter & Model & w/o oxidation & $1000^{\circ} \mathrm{C}$ & $1200^{\circ} \mathrm{C}$ & $1400^{\circ} \mathrm{C}$ \\
\hline \multicolumn{6}{|l|}{$\begin{array}{l}\text { Moissanite } 6 \mathrm{H} \\
98-016-4972^{[15]}\end{array}$} \\
\hline \multirow{7}{*}{$\begin{array}{l}\text { Crystal system: } \\
\text { Space group: } \\
\mathrm{a}=\mathrm{b}=(\AA) \\
\mathrm{C}=(\AA) \\
\text { Alpha }=\operatorname{Beta}\left({ }^{\circ}\right): \\
\text { Gamma }\left({ }^{\circ}\right): \\
\text { Wt\%: }\end{array}$} & Hexagonal & Hexagonal & Hexagonal & Hexagonal & Hexagonal \\
\hline & P 63 m c & P 63 m c & P 63 m c & P 63 m c & P 63 m c \\
\hline & 3.0820 & $3.08129(7)$ & $3.08084(7)$ & $3.08009(1)$ & $3.08143(0)$ \\
\hline & 15.0920 & $15.11467(6)$ & $15.12063(5)$ & $15.11809(5)$ & $15.12258(4)$ \\
\hline & 90 & 90 & 90 & 90 & 90 \\
\hline & 120 & 120 & 120 & 120 & 120 \\
\hline & & 62.717 & 22.061 & 39.492 & 30.706 \\
\hline \multicolumn{6}{|l|}{$\begin{array}{l}\text { Moissanite 4H } \\
98-016-4971^{[15]}\end{array}$} \\
\hline \multirow{7}{*}{ 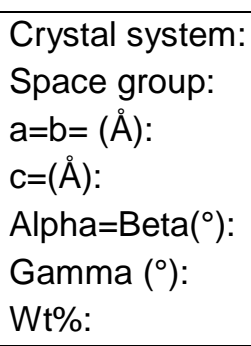 } & Hexagonal & Hexagonal & Hexagonal & Hexagonal & Hexagonal \\
\hline & $\mathrm{P} 63 \mathrm{~m} \mathrm{c}$ & P $63 \mathrm{~m} \mathrm{c}$ & P $63 \mathrm{~m} \mathrm{c}$ & P 63 m c & P 63 m c \\
\hline & 3.0820 & $3.07769(8)$ & $3.08430(2)$ & $3.07975(8)$ & $3.08144(0)$ \\
\hline & 10.0610 & $10.07763(2)$ & $10.10144(7)$ & $10.08449(1)$ & $10.08571(1)$ \\
\hline & 90 & 90 & 90 & 90 & 90 \\
\hline & 120 & 120 & 120 & 120 & 120 \\
\hline & & 37.283 & 14.148 & 23.338 & 35.738 \\
\hline \multicolumn{6}{|l|}{ Other phases: } \\
\hline Wt\%: & & & 63.801 & 47.170 & 34.556 \\
\hline
\end{tabular}

Table 4. Peaks of $\mathrm{SiC} 6 \mathrm{H}$ polytype and $\mathrm{SiC} 4 \mathrm{H}$ polytype.

\begin{tabular}{|c|c|c|c|c|c|}
\hline $2 \theta$ (degree) & SiC Polytype & \multicolumn{5}{|c|}{ FWHM } \\
\cline { 3 - 6 } (w/o oxidation) & & w/o oxidation & $1000^{\circ} \mathrm{C}$ & $1200{ }^{\circ} \mathrm{C}$ & $1400^{\circ} \mathrm{C}$ \\
\hline 34.095 & $6 \mathrm{H}$ & 0.180 & 0.060 & 0.060 & 0.120 \\
\hline 41.390 & $6 \mathrm{H}$ & 0.120 & 0.060 & 0.060 & 0.080 \\
\hline 45.330 & $6 \mathrm{H}$ & 0.100 & 0.200 & 0.060 & 0.160 \\
\hline 34.745 & $4 \mathrm{H}$ & 0.120 & 0.060 & 0.060 & 0.100 \\
\hline 43.289 & $4 \mathrm{H}$ & 0.120 & 0.160 & 0.160 & 0.160 \\
\hline 57.294 & $4 \mathrm{H}$ & 0.320 & 0.080 & 0.080 & 0.080 \\
\hline
\end{tabular}


The a-axis value for $6 \mathrm{H}-\mathrm{SiC}$ at room temperature was at $3.0815 \AA^{[16]}$ and 3.0810 $\AA$ [17]. For c-axis value was at $15.117 \AA$ [16] and $15.092 \AA{ }^{[17]}$. According to ${ }^{[16]}$ the a-axis and $\mathrm{c}$-axis were increased as temperature rising. Our results showed a-axis and c-axis value for $6 \mathrm{H}-\mathrm{SiC}$ were around these values. For $4 \mathrm{H}-\mathrm{SiC}$, at room temperature was at $3.079 \AA$, $3.090 \AA^{[18]}$ and $3.081 \AA^{[17]}$. For caxis value was $10.053 \AA$ [18] and $10.061 \AA$ [17]. Our results for a-axis value were not significanly different, but our findings for the $c$-axis values slightly higher than reported by [17,18]. SiC layer performance corelate to the kernel nuclear fuel must be done by another testing such as mechanical and/or corrosion test. In this study only show how many weight the SiC converted into other phases during oxidation. That we know the change of phases, would changes the surface properties such as its chemical, mechanical and corrosion properties.

\section{CONCLUSIONS}

Two samples of SiC successfully oxidized at high temperature in air atmosphere. The samples undergo to weight gain during oxidation. Analysis on diffraction pattern using Rietveld method in GSAS software, capable to determine the weight percentage of phases and the lattice parameter changes. For the $6 \mathrm{~S}$ showed the highest weight changes at $1200^{\circ} \mathrm{C}$, this was correlated to the amount of $6 \mathrm{H}-\mathrm{SiC}$ phase that converted into the other phases. The peak shifted and broadening were clearly occurred in the diffraction pattern. The peak shifted tendency in samples $46 \mathrm{~S}$ similar to the lattice parameter value between the as received $\mathrm{SiC}$ and the oxidation samples. However, for peak broadening tendency to had bigger crystallite size. The $6 \mathrm{H}-\mathrm{SiC}$ showed highly oxidated compare to the $4 \mathrm{H}-\mathrm{SiC}$ at this range temperature. Oxidation at $1400{ }^{\circ} \mathrm{C}$ showed the $6 \mathrm{H}-\mathrm{SiC}$ in both samples converted into other phases more than $50 \%$ of weight percentage.

\section{ACKNOWLEDGEMENT}

This work was supported by the Center for Nuclear Fuel Technology BATAN. The authors would like to thank Professor Dr. Ridwan, Ir. Sungkono, MT, Ir. Ratih Langenati, MT and Mahpudin for their support.

\section{REFERENCES}

[1] Magnani, G., Brentari, A., Burresi, E., \& Raiteri, G. (2014). Pressureless sintered silicon carbide with enhanced mechanical properties obtained by the two-step sintering method. Ceramics International, 40(1), 1759-1763.

[2] Roy, J., Chandra, S., Das, S., \& Maitra, S. (2014). Oxidation Behaviour of Silicon Carbide-A Review. Rev. Adv. Mater. Sci, 38, 29-39.

[3] Setiawan, J., Pranjono, Sigit, Futichah, Langenati, R., \& Ridwan. (2015). Karakteristik termofisika komposit non woven SiOC dengan penambahan serbuk SiC. Jurnal Teknologi Bahan Nuklir, 11(1), 38-47.

[4] Park, D. J., Jung, Y. I., Kim, H. G., Park, J. Y., \& Koo, Y. H. (2014). Oxidation behavior of silicon carbide at 1200 $C$ in both air and water vapor rich environments. Corrosion Science, 88, 416-422.

[5] Terrani, K. A., \& Silva, C. M. (2015). High temperature steam oxidation of SiC coating layer of TRISO fuel particles. Journal of Nuclear Materials, 460, 160-165.

[6] Hou, X. M., Chou, K. C., \& Li, F. S. (2009). A new treatment for kinetics of oxidation of silicon carbide. Ceramics International, 35(2), 603-607.

[7] Quanli, J., Haijun, Z., Suping, L., \& Xiaolin, J. (2007). Effect of particle size on oxidation of silicon carbide powders. Ceramics international, 33(2), 309-313.

[8] Hijikata, Y., Yaguchi, H., Yoshida, S., \& Yagi, S. (2012). Thermal Oxidation 
Mechanism of Silicon Carbide. INTECH Open Access Publisher.

[9] Hijikata, Y., Yaguchi, H., \& Yoshida, S. (2009). A kinetic model of silicon carbide oxidation based on the interfacial silicon and carbon emission phenomenon. Applied physics express, 2(2), 021203.

[10] Gupta, S. K., \& Akhtar, J. (2011). Thermal Oxidation of Silicon Carbide (SiC)-Experimentally Observed Facts. INTECH Open Access Publisher.

[11] Liu, R., Liu, B., Zhang, K., Liu, M., Shao, Y., \& Tang, C. (2014). High temperature oxidation behavior of $\mathrm{SiC}$ coating in TRISO coated particles. Journal of Nuclear Materials, 453(1), 107-114.

[12] Sharma, Y. K., Li, F., Jennings, M. R., Fisher, C. A., Pérez-Tomás, A., Thomas, S., \& Mawby, P. A. (2015). High temperature $\left(1200-1400{ }^{\circ} \mathrm{C}\right)$ dry oxidation of $3 \mathrm{C}-\mathrm{SiC}$ on silicon. Journal of Electronic Materials, 44(11), 41674174.

[13] A.C. Larson and R.B. Von Dreele. (2000). "General Structure Analysis System (GSAS)", Los Alamos National Laboratory Report LAUR 86-748

[14] B. H. Toby. (2001). EXPGUI, a graphical user interface for GSAS, J. Appl. Cryst. 34, 210-213

[15] ----------, (2012). ICSD Database FIZ Karlsruhe 2012-1. Germany.

[16] Munro, R.G. (1997). Material Propeties of a Sintered $\alpha-S i C$. J.Phys.Chem Ref. Data,Vol.26,No.5.pp 1195 - 1203.

[17] Snead, et.al. (2007). Handbook of SiC properties for fuek performance modelling. Journal of Nuclear Materials 371.pp329-377

[18] Nuruzzaman, Md., et.al. (2015). Strtural, elastic and electronic properties of $2 \mathrm{H}$ - and $4 \mathrm{H}-\mathrm{SiC}$. Int. Journal of Engineering Research and Applications, Vol.5, Issue.5, pp $48-52$. 
